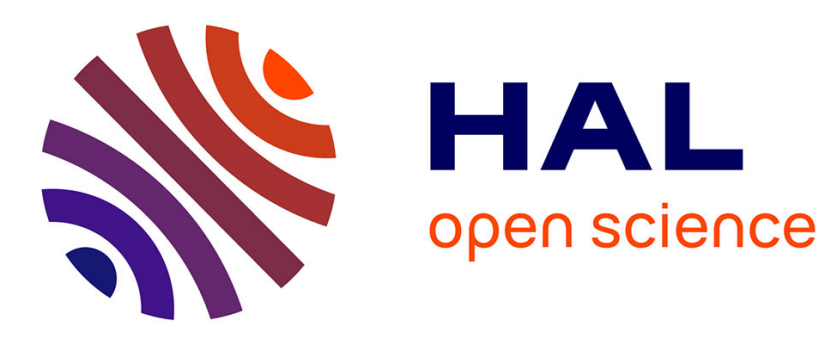

\title{
Synergistic effects of dexamethasone and quinolones on human-derived tendon cells
}

Judith Sendzik, Mehdi Shakibaei, Monika Schäfer-Korting, Hartmut Lode, Ralf Stahlmann

\section{- To cite this version:}

Judith Sendzik, Mehdi Shakibaei, Monika Schäfer-Korting, Hartmut Lode, Ralf Stahlmann. Synergistic effects of dexamethasone and quinolones on human-derived tendon cells. International Journal of Antimicrobial Agents, 2010, 35 (4), pp.366. 10.1016/j.ijantimicag.2009.10.009 . hal-00567277

\section{HAL Id: hal-00567277 \\ https://hal.science/hal-00567277}

Submitted on 20 Feb 2011

HAL is a multi-disciplinary open access archive for the deposit and dissemination of scientific research documents, whether they are published or not. The documents may come from teaching and research institutions in France or abroad, or from public or private research centers.
L'archive ouverte pluridisciplinaire HAL, est destinée au dépôt et à la diffusion de documents scientifiques de niveau recherche, publiés ou non, émanant des établissements d'enseignement et de recherche français ou étrangers, des laboratoires publics ou privés. 


\section{Accepted Manuscript}

Title: Synergistic effects of dexamethasone and quinolones on human-derived tendon cells

Authors: Judith Sendzik, Mehdi Shakibaei, Monika

Schäfer-Korting, Hartmut Lode, Ralf Stahlmann

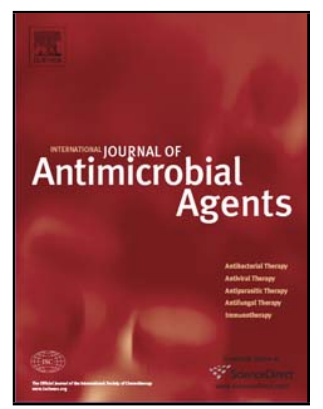

PII: $\quad$ S0924-8579(09)00483-X

DOI: $\quad$ doi:10.1016/j.ijantimicag.2009.10.009

Reference: $\quad$ ANTAGE 3162

To appear in: International Journal of Antimicrobial Agents

Received date: $\quad$ 28-7-2009

Revised date: $\quad 21-9-2009$

Accepted date: 6-10-2009

Please cite this article as: Sendzik J, Shakibaei M, Schäfer-Korting M, Lode H, Stahlmann R, Synergistic effects of dexamethasone and quinolones on humanderived tendon cells, International Journal of Antimicrobial Agents (2008), doi:10.1016/j.ijantimicag.2009.10.009

This is a PDF file of an unedited manuscript that has been accepted for publication. As a service to our customers we are providing this early version of the manuscript. The manuscript will undergo copyediting, typesetting, and review of the resulting proof before it is published in its final form. Please note that during the production process errors may be discovered which could affect the content, and all legal disclaimers that apply to the journal pertain. 


\section{Synergistic effects of dexamethasone and quinolones on human- derived tendon cells}

Judith Sendzik ${ }^{a}$, Mehdi Shakibaei ${ }^{b}$, Monika Schäfer-Korting ${ }^{\mathrm{c}}$, Hartmut Lode ${ }^{\mathrm{a}}$, Ralf Stahlmann ${ }^{a, *}$

a Institute of Clinical Pharmacology and Toxicology, Charité - Universitätsmedizin Berlin, Campus Benjamin Franklin, Garystr. 5, 14195 Berlin, Germany

${ }^{\mathrm{b}}$ Institute of Anatomy, Ludwig-Maximilians-Universität München, Pettenkoferstr. 11, 80336 München, Germany

${ }^{c}$ Institute of Pharmacy, Pharmacology and Toxicology, Freie Universität Berlin, Königin-Luise-Str. 2-4, 14195 Berlin, Germany

\section{ARTICLE INFO}

Article history:

Received 28 July 2009

Accepted 6 October 2009

Keywords:

Tenocytes

Glucocorticoids

Dexamethasone

Quinolones

Ciprofloxacin

Levofloxacin 
* Corresponding author.

E-mail address: ralf.stahlmann@charite.de (R. Stahlmann). 


\section{ABSTRACT}

Quinolones and glucocorticoids are frequently used drugs that may cause tendinopathy as a rare adverse effect. We exposed human tenocyte cultures to the steroid dexamethasone alone or in combination with either ciprofloxacin or levofloxacin at concentrations of $3 \mathrm{mg} / \mathrm{L}$ and $10 \mathrm{mg} / \mathrm{L}$. At concentrations corresponding to peak levels in plasma and tissues during therapy (ca. $3-10 \mathrm{mg} / \mathrm{L}$ ), ciprofloxacin caused a significant decrease in collagen type I and the $\beta_{1}$-integrin receptor. In contrast, no corresponding effect was induced by $3 \mathrm{mg} / \mathrm{L}$ levofloxacin. With both quinolones at $3 \mathrm{mg} / \mathrm{L}$ and $10 \mathrm{mg} / \mathrm{L}$, the amount of matrix metalloproteinase-1 (MMP-1) and MMP-13 was increased. In addition, 3 mg/L ciprofloxacin and $10 \mathrm{mg} / \mathrm{L}$ levofloxacin activated caspase-3. Apoptotic changes were confirmed by electron microscopy. Incubation of human tenocytes with dexamethasone decreased the main matrix protein collagen type I, the transmembrane $\beta_{1}$-integrin receptor and the cytoskeleton protein vinculin, but only at the high concentrations tested $(0.1 \mu \mathrm{M}$ or $10 \mu \mathrm{M})$. Concentrations of $0.1 \mu \mathrm{M}$ and 10 $\mu \mathrm{M}$ dexamethasone increased the amount of MMPs and activated caspase- 3 as an indicator of apoptosis. Combined exposure to quinolones and dexamethasone led to more pronounced effects in tenocyte cultures at most of the analysed endpoints. The clinical observations of an increased risk of quinolone-induced tendinopathy by glucocorticoids are supported by these in vitro data. 


\section{Introduction}

Glucocorticoids and quinolones are commonly used agents for ambulant or inpatient therapy. The steroids are used systemically for several acute and chronic diseases such as chronic bronchopulmonary diseases as well as for immunosuppression following organ transplantation. The use of quinolones has increased during recent years because of the increasing resistance of pneumococci and other bacteria to $\beta$ lactams and macrolides [1]. Tendinopathies are rare but severe side effects that have been observed for both classes of drugs [2-10]. The term 'tendinopathy' comprises several forms of tendon damage from a reversible inflammation (tendinitis) up to tendon rupture requiring surgical intervention. Several case reports and retrospective studies indicate that the risk for tendinopathy is increased by concomitant use of glucocorticoids and quinolones [11-14]. Little is known about cellular alterations as an underlying cause of this adverse effect.

Tendons possess high tensile strength, mechanic stability and elastic properties. These characteristics are mediated by their extracellular matrix predominantly consisting of collagen type I fibrils and additional elastic fibres [15]. Embedded in this network of fibrils are tenocytes. These cells produce all components of the extracellular matrix and consequently play an important role in the structure and function of the tendon $[16,17]$. Cell-cell and cell-matrix interactions are mediated via transmembrane signal transduction receptors such as $\beta_{1}$-integrins. They activate different signal transduction pathways, such as the mitogen-activated protein (MAP) kinase pathway, and thus control proliferation, differentiation and survival of tenocytes $[18,19]$. Undisturbed cell-matrix interactions are essential for cell viability, and inhibition of the MAP kinase pathway can induce programmed cell death $[20,21]$. 
We have previously described the effects of quinolones on tenocytes in vivo and in vitro. In vivo data have shown that tendons of quinolone-treated rats and dogs exhibited morphological and biochemical changes in the extracellular matrix and $\beta_{1}$ integrins [22-24]. In vitro experiments with quinolone-incubated human-derived tenocytes revealed possible mechanisms in more detail. We found changes in the extracellular matrix, $\beta_{1}$-integrin receptors as well as in signalling proteins of the MAP kinase pathway. In addition, probably as a consequence of the cell-cell and cellmatrix disturbance, apoptosis was induced in human tenocytes at concentrations of quinolones that are achieved in human plasma and tissues during therapy with these drugs [25].

Experimental studies performed to elucidate glucocorticoid-induced tendinopathies are scarce and somewhat controversial. In vitro studies revealed degenerative changes, reduced synthesis of collagen type I and proteoglycans, as well as decreased cell proliferation, viability and metabolism following glucocorticoid exposure [26-30]. Experimental evidence on the effects of steroids in combination with quinolones is even more limited. The in vitro experiments described here were conducted to study in more detail the effects of a glucocorticoid on human-derived tenocytes alone and in combination with a quinolone. Concentrations tested were orientated at maximum concentrations achievable in plasma during therapy. 


\section{Materials and methods}

\subsection{Cell culture}

Finger tendon explants obtained during surgery were used to isolate primary human tenocytes [25]. Briefly, following non-enzymatic isolation, cells were expanded in monolayers and multiplied. Tenocytes were then pre-cultured on Petri dishes for $24 \mathrm{~h}$ at $37{ }^{\circ} \mathrm{C}$ in a humidified atmosphere with $5 \% \mathrm{CO}_{2}$ before incubation for $1-4$ days with dexamethasone and/or a quinolone under the same conditions. The growth medium was composed of growth medium Ham's F-12 and Dulbecco's MEM (50:50) supplemented with $5 \%$ fetal calf serum (FCS). For incubation, the growth medium was supplemented with: $0.1 \mathrm{nM}$ (ca. $0.039 \mu \mathrm{g} / \mathrm{L}$ ), $1 \mathrm{nM}$ (ca. $0.39 \mu \mathrm{g} / \mathrm{L}$ ), $0.1 \mu \mathrm{M}$ (ca. $39 \mu \mathrm{g} / \mathrm{L}$ ) or $10 \mu \mathrm{M}$ (ca. $3925 \mu \mathrm{g} / \mathrm{L}$ ) dexamethasone; or $3 \mathrm{mg} / \mathrm{L}$ or $10 \mathrm{mg} / \mathrm{L}$ of either ciprofloxacin or levofloxacin; or $3 \mathrm{mg} / \mathrm{L}$ quinolone plus $0.1 \mathrm{nM}$ dexamethasone; or 10 $\mathrm{mg} / \mathrm{L}$ quinolone plus $1 \mathrm{nM}$ dexamethasone. Controls were cultured in growth medium without addition of a quinolone or dexamethasone for 1-4 days. Samples for Western blotting were collected after 1, 2, 3 and 4 days of drug exposure, and samples for electron microscopy were collected after a 4-day drug exposure only.

\subsection{Antibodies, drugs and culture medium}

Polyclonal (rabbit anti-bovine) anti-collagen type I (AB749) antibody and alkaline phosphatase-conjugated sheep anti-mouse as well as sheep anti-rabbit secondary antibodies (AP303A, AP304A) were purchased from Chemicon International, Inc. (Temecula, CA). Monoclonal anti- $\beta_{1}$-integrin (141720) antibody was obtained from Transduction (Heidelberg, Germany). Monoclonal anti-vinculin (V9131) was obtained from Sigma-Aldrich (Munich, Germany). Monoclonal anti-matrix metalloproteinase 
(MMP)-1 (MAB900), anti-MMP-13 (MAB511) and polyclonal anti-active caspase-3 (AF835) antibodies were provided by R\&D Systems, Inc., (Heidelberg, Germany). Culture medium containing $5 \% \mathrm{FCS}, 25 \mu \mathrm{g} / \mathrm{mL}$ ascorbic acid, $50 \mathrm{lU} / \mathrm{mL}$ streptomycin, $50 \mathrm{IU} / \mathrm{mL}$ penicillin, $2.5 \mu \mathrm{g} / \mathrm{mL}$ amphotericin B, $1 \%$ glutamine and $1 \%$ essential amino acids was obtained from Seromed (Munich, Germany). O.C.T. compound embedding medium and trypsin/ethylene diamine tetra-acetic acid (EDTA) (EG 3.4.21.4) were purchased from Sigma-Aldrich. Epon was obtained from Plano (Marburg, Germany). The two quinolones were used as commercially available solutions for intravenous (i.v.) infusion [Ciprobay ${ }^{\circledR} 400$ Infusionslösung (Bayer, Leverkusen, Germany) and Tavanic $^{\circledR}$ i.v. 500 mg (Aventis, Frankfurt am Main, Germany)]. Dexamethasone was purchased from Sigma-Aldrich and a $10 \mathrm{mM}$ stock solution was prepared in ethanol. First, the solutions with the highest concentration used here $(10 \mathrm{mg} / \mathrm{L}$ quinolone and $10 \mu \mathrm{M}$ dexamethasone) were prepared from the quinolone or glucocorticoid preparations plus culture medium. Then, the other solutions were made by further dilution with culture medium. For the incubation media containing quinolone plus dexamethasone, the glucocorticoid was added at the indicated concentration to quinolone-containing culture media.

\subsection{Electron microscopy}

To asses the formation of tenocytes and tenocyte extracellular matrix in the monolayer cultures after 4 days of incubation at the ultrastructural level, transmission electron microscopy (TEM) was performed as previously described in detail [24]. Briefly, cells were fixed in Karnovsky's solution, post-fixed in $1 \% \mathrm{OsO}_{4}$ and then rinsed and subsequently dehydrated in an ascending alcohol series and finally embedded in Epon. Sections of ca. 50-70 nm were cut on a Reichert-Jung Ultracut E 
microtome (Heidelberg, Germany). The ultrathin sections were contrasted with 2\% uranyl acetate/lead citrate. A transmission electron microscope (TEM 10; Zeiss, Jena, Germany) was used to examine the tenocytes cultures.

\subsection{Western blot analysis}

Western blot analysis was performed as described previously in detail [21]. Briefly, tenocyte proteins were extracted with lysis buffer [50 mM Tris/HCl $(\mathrm{pH} 7.2)], 150 \mathrm{mM}$ $\mathrm{NaCl}, 1 \%(\mathrm{v} / \mathrm{v})$ Triton $\mathrm{X}-100,1 \mathrm{mM}$ sodium orthovanadate, $50 \mathrm{mM}$ sodium pyrophosphate, $100 \mathrm{mM}$ sodium fluoride, $0.01 \%(\mathrm{v} / \mathrm{v})$ aprotinin, $4 \mu \mathrm{g} / \mathrm{mL}$ pepstatin $\mathrm{A}$, $10 \mu \mathrm{g} / \mathrm{mL}$ leupeptin and $1 \mathrm{mM}$ PMSF for $30 \mathrm{~min}$ on ice. The total protein concentration was determined using the bicinchoninic acid system Uptima (Interchim, Montluçon, France) with bovine serum albumin as a standard. Adjusted to an equal total cell protein concentration, samples were separated using sodium dodecyl sulphate polyacrylamide gel electrophoresis (SDS-PAGE) $(5 \%, 7.5 \%, 10 \%$ or $12 \%$ gels) under reducing conditions and proteins were transferred onto nitrocellulose membranes. Western blotting was performed with different primary antibodies and alkaline phosphatase-conjugated secondary antibodies. To reveal the specific antigen-antibody complexes, nitro blue tetrazolium and 5-bromo-4-chloro-3indolylphosphate ( $p$-toluidine salt; Pierce, Rockford, IL) were used as substrates for alkaline phosphatase. Immunoblots were semiquantitatively analysed using the computer program ‘Quantity one’ (Bio-Rad, Munich, Germany). Experiments were performed triplicate. 


\section{Results}

\subsection{Culture of human-derived tenocytes}

Tenocytes were isolated by a non-enzymatic method via outgrowth out of a dissected finger tendon. After ca. 1 week, tenocytes continuously migrated from the explant, adhered to Petri dishes and proliferated. Cells were plated with $12 \mathrm{~mL}$ of cell culture medium in a $\mathrm{T} 75$ flask and incubated at $37^{\circ} \mathrm{C}$ in $5 \% \mathrm{CO}_{2}$. These primary tenocytes showed a typical elongated cell shape with long cytoplasmic processes. Three to five days later, when the cell density had approached confluence, these cells were removed using $0.05 \%$ trypsin/1.0 mM EDTA and were passaged up to a maximum of ten times in monolayer culture to gain sufficient cells.

\subsection{Ultrastructural changes in tenocytes}

The effect of the glucocorticoid and/or quinolones on tenocytes was examined by TEM. Serum-starved primary isolated tenocytes were either exposed to glucocorticoid and/or a quinolone or were left unexposed. Untreated control monolayer tenocytes showed a fibroblast-like shape, numerous small ridge-like or cuspidal surface processes, a large mostly euchromatic nucleus with nucleoli and well structured cytoplasm organelles, a well developed rough endoplasmic reticulum (ER), mitochondria and a large Golgi apparatus from the beginning of cultivation onwards (Fig. 1A,B). They produced a thin, pericellular matrix rim consisting of fine irregularly running filaments that could be demonstrated extracellularly on the cell surface (inset Fig. 1A). By contrast, when the tenocytes were exposed to either ciprofloxacin (Fig. 1C), levofloxacin (Fig. 1D) or dexamethasone (Fig. 1E) they showed degenerative changes such as swelling of the rough ER and clustering of swollen mitochondria and degeneration of other cell organelles. These changes 
included areas of condensed heterochromatin in the cell nuclei. The flattened monolayer tenocytes became more and more rounded, lost their microvilli-like processes and became apoptotic (Fig. 1C-E). Both quinolones caused alterations at concentrations that are usually achieved under therapeutic conditions $(3-10 \mathrm{mg} / \mathrm{L})$. Dexamethasone-exposed tenocytes showed the abovementioned cellular alterations even at the lowest concentration tested $(0.1 \mathrm{nM})$.

Tenocytes that were exposed to the combination of $3 \mathrm{mg} / \mathrm{L}$ quinolone plus $0.1 \mathrm{nM}$ dexamethasone showed more pronounced degenerative changes such as multiple vacuoles, swelling of the rough ER, clustering of swollen mitochondria and Golgi apparatus (Fig. 1F,G) as well as degeneration of other cell organelles compared with those after treatment with a single drug alone.

\subsection{Biochemical changes in the extracellular matrix and cytoskeleton}

Western blotting was used to analyse biochemical changes at the protein level of tenocytes. The highest dexamethasone concentration tested $(10 \mu \mathrm{M})$ decreased collagen type I by $35 \%$. Effects with ciprofloxacin at both concentrations $(3 \mathrm{mg} / \mathrm{L}$ and $10 \mathrm{mg} / \mathrm{L}$ ) and a combination of both drugs at low concentrations caused a similar decrease. A synergistic effect of $10 \mathrm{mg} / \mathrm{L}$ ciprofloxacin plus $1 \mathrm{nM}$ dexamethasone was observed. Collagen type I production (Fig. 2) and synthesis of the $\beta_{1}$-integrin (Fig. 3) were drastically reduced.

Comparison between the collagen and $\beta_{1}$-integrin data showed that the $\beta_{1}$-integrins reacted more sensitively than the matrix protein. Therapeutically relevant low concentrations of $0.1 \mathrm{nM}$ dexamethasone did not induce such changes, but at the 
higher concentration of $1 \mathrm{nM}$ dexamethasone the variability was high, since some, but not all, samples showed changes. Levofloxacin in combination with dexamethasone caused similar changes, but only at concentrations of $\geq 10 \mathrm{mg} / \mathrm{L}$ levofloxacin (data not shown).

The mean amount of the cytoskeleton protein vinculin was suppressed by the two higher concentrations of dexamethasone to $62 \%(0.1 \mu \mathrm{M})$ and $20 \%(10 \mu \mathrm{M})$ of the dexamethasone mean control value, whereas no changes were observed for $0.1 \mathrm{nM}$ and $1 \mathrm{nM}$ compared with the untreated control (Fig. 4). Moreover, incubation with ciprofloxacin alone resulted in a strong decrease of vinculin, which was more pronounced than after incubation of the tenocytes with levofloxacin (data not shown).

All changes in protein concentrations occurred time dependently over the study period of 4 days, and with a combined exposure of dexamethasone plus a quinolone the changes were detectable at an earlier time point during the 4-day period (time dependency not shown).

\subsection{Alterations in the amount of matrix metalloproteinases}

The effects of levofloxacin and ciprofloxacin alone or in combination with dexamethasone on MMP-1 and MMP-13 were very pronounced. As described previously, densitometric analysis revealed an increase in MMP-13 of ca. 7-fold or 18-fold compared with controls following incubation for 4 days with $3 \mathrm{mg} / \mathrm{L}$ or $10 \mathrm{mg} / \mathrm{L}$ ciprofloxacin, respectively [25]. Incubation with $0.1 \mu \mathrm{M}$ or $10 \mu \mathrm{M}$ dexamethasone also evoked a clear-cut upregulation of MMP-1 and MMP-13 (Figs 5 and 6). 
Following exposure of the cells to a combination of a quinolone plus dexamethasone, changes occurred more rapidly than after exposure to a quinolone alone and were even more pronounced. After 3 days in culture with $10 \mathrm{mg} / \mathrm{L}$ ciprofloxacin or levofloxacin plus $1 \mathrm{nM}$ dexamethasone the increase in MMP-13 was approximately twice as pronounced in comparison with the effects with dexamethasone alone. After 4 days in culture, the amount of MMP-13 increased significantly with either $10 \mathrm{mg} / \mathrm{L}$ ciprofloxacin or levofloxacin plus $1 \mathrm{nM}$ dexamethasone (Figs 6-8).

\subsection{Activation of caspase-3}

The amount of the apoptosis marker activated caspase- 3 was very low in control cells (0-0.03 densitometric units). No significant change was observed after incubation with $0.1 \mathrm{nM}$ or $1 \mathrm{nM}$ dexamethasone; however, it was increased by the two higher concentrations of the glucocorticoid (Fig. 9). With $10 \mu \mathrm{M}$ dexamethasone the effect was noticed 1 day earlier compared with the $0.1 \mu \mathrm{M}$ concentration (data not shown).

A time- and concentration-dependent increase in caspase-3 was observed following incubation with the quinolones [25]. In comparison with incubation with $0.1 \mathrm{nM}$ dexamethasone alone, combined exposure of the cells to $3 \mathrm{mg} / \mathrm{L}$ of either ciprofloxacin or levofloxacin plus $0.1 \mathrm{nM}$ dexamethasone increased the concentration of caspase-3 from Day 3 onwards (Fig. 8B). Similar effects occurred following incubation with $10 \mathrm{mg} / \mathrm{L}$ quinolone plus $1.0 \mathrm{nM}$ dexamethasone. However, for 10 $\mathrm{mg} / \mathrm{L}$ ciprofloxacin plus $1.0 \mathrm{nM}$ dexamethasone the changes were less pronounced than for $3 \mathrm{mg} / \mathrm{L}$ ciprofloxacin plus $0.1 \mathrm{nM}$ dexamethasone. The reason for this unexpected finding is unknown. 


\section{Discussion}

In a previous publication we have described that the quinolones ciprofloxacin and levofloxacin caused a time- and concentration-dependent decline in extracellular matrix and key signalling proteins in human tenocytes in vitro [25]. Furthermore, an increase in the apoptosis marker activated caspase-3 as well as characteristic ultrastructural degenerative features were observed in the quinolone-treated tenocytes. These alterations occurred at concentrations that are readily achieved in plasma and tissues of patients during therapy with these quinolones. In this continuative study, the effects of the glucocorticoid dexamethasone either alone or in combination with one of the quinolones ciprofloxacin or levofloxacin were analysed in our in vitro tenocyte model to study a possible synergism between glucocorticoids and quinolones. Dexamethasone was also studied at therapeutically relevant concentrations. A mean peak plasma concentration $\left(C_{\max }\right)$ of $8.4 \pm 3.6 \mu \mathrm{g} / \mathrm{L}$ (ca. 210 $\mathrm{nM}$ ) has been reported following an oral dose of $1 \mathrm{mg}$ dexamethasone [31-34].

The effects of dexamethasone alone were less distinct than those observed with quinolones and occurred only at the two higher concentrations tested. However, by combining ciprofloxacin or levofloxacin with dexamethasone at therapeutically relevant concentrations, synergistic effects on tenocytes were obvious for most of the analysed proteins compared with the effects observed with either drug alone. Importantly, during the culture period of 4 days most of the effects occurred earlier with a drug combination than with exposure to one drug alone. This supports the clinical observations of an increased risk for quinolone-induced tendinopathy by concomitant use of glucocorticoids [7]. 
Whereas the quinolone-induced tendon disorders are widely accepted as typical adverse effects of these drugs, the association of glucocorticoid use with a tendinopathy is discussed controversially. In vitro or in vivo data of the effects of glucocorticoids on tendon or cartilage are scarce. The observed decline in collagen type I following incubation with $10 \mu \mathrm{M}$ dexamethasone in our experiments is in agreement with the findings of Wong et al. [27]. In their in vitro model with human tenocytes, $1 \mu \mathrm{M}$ dexamethasone led to a decrease in cell proliferation, viability and collagen type I production [27]. Moreover, reduced expression of collagen type I mRNA and procollagen type I and II was shown in two studies with tenocytes of chick embryos $[35,36]$. A concentration-dependent reduction in the number of tenocytes and collagen synthesis was also detected with rat tail tenocytes when exposed over extended time periods [37].

All data indicate a direct effect of dexamethasone on the proliferation of tendon cells. Our finding of an increased amount of MMP-1 and MMP-13 following incubation with $0.1 \mu \mathrm{M}$ and $10 \mu \mathrm{M}$ dexamethasone indicates an additional catabolic effect on the extracellular tendon matrix. MMP-1 and MMP-13 are able to cleave collagen type I [38-40]. Few data on the glucocorticoid-mediated regulation of MMP production in tendons are available. Dexamethasone inhibited the upregulation of both MMP-2 and MMP-9 induced by the attachment of tendon cells to collagen type I [41]. In chondrocytes, reduced MMP production after incubation with dexamethasone was also detected, but in these experiments cells were pre-stimulated with cytokines to induce MMP production [42-44]. Obviously the effect of glucocorticoids on MMP expression differs depending on MMP species (collagenases versus gelatinases), cytokine pre-treatment and various other conditions. 
The decreased amount of $\beta_{1}$-integrin receptors in tenocytes following dexamethasone exposure can be interpreted as a sign of a slight impact on the initial step of signalling pathways such as the MAP kinase pathway as well as on cell-cell and cell-matrix interactions. Higher concentrations of dexamethasone induced apoptosis as indicated by increased caspase-3 activity as a downstream effector caspase and by pro-apoptotic ultrastructural changes. Wong et al. [27] did not find an indication for programmed cell death following dexamethasone incubation in their tenocyte in vitro model, which might be explained by the lower concentrations tested and the other endpoints used. Other publications describe that glucocorticoids induce apoptosis in human [45], rodent [46] or bovine [47] chondrocytes.

The mechanism of the synergistic effect between glucocorticoids and quinolones is still unknown. Data from in vivo and in vitro studies or clinical trials are scarce. An in vitro study with triamcinolone acetonide $(100 \mu \mathrm{g} / \mathrm{mL})$ combined with ciprofloxacin (100 $\mu \mathrm{g} / \mathrm{mL}$ ), pefloxacin or sparfloxacin showed enhanced cytotoxicity (mitochondrial dehydrogenase activity; MTT test) in comparison with incubation with the quinolone alone [48]. However, triamcinolone acetonide alone was more cytotoxic than ciprofloxacin in this model [48]. The origin of the human tendon cells (Achilles tendon versus finger tendon cells), the details of the experimental conditions and the respective glucocorticoid differ from our experiments.

In rats, dexamethasone inhibited pefloxacin-induced changes in Achilles tendons [49]. This is in contrast to clinical observations and to our results but might be explained by the short treatment period of only $24 \mathrm{~h}$. In a typical clinical situation, 
patients are treated chronically with glucocorticoids for indications such as pulmonary diseases or following organ transplantation [14,50].

Taken together, the effects of quinolones on human tenocytes were significantly intensified by dexamethasone depending on the quinolone, the concentration used and the duration of exposure. Our data support the clinical observations that treatment with glucocorticoids has to be considered an important risk factor for quinolone-induced tendinopathy.

\section{Acknowledgments}

The authors thank Mrs Angelika Steuer, Mrs Angelika Hartje and Mr Jörg Romahn for expert technical assistance, Mrs Christine Gericke for help in preparing the figures, Mrs Heidi Pretorius for carefully proof-reading the manuscript, and Dr Gundula Schulze-Tanzil and Dr Philippe de Souza for additional support.

\section{Funding}

This study was supported in part by a grant from Sonnenfeld-Stiftung, Berlin.

\section{Competing interests}

JS is currently employed at Bayer-Schering Pharma AG. HL is a consultant/speaker for Astellas Pharma, Bayer-Schering Pharma, Sanofi-aventis, Janssen, Pfizer and Wyeth. RS has received lecture fees from MSD. MS and MS-K declare no competing interests.

\section{Ethical approval}

Not required. 


\section{References}

[1] van Bambeke F, Reinert RR, Appelbaum PC, Tulkens PM, Peetermans WE. Multidrug-resistant Streptococcus pneumoniae infections: current and future therapeutic options. Drugs 2007;67:2355-82.

[2] Smith AG, Kosygan K, Williams H, Newman RJ. Common extensor tendon rupture following corticosteroid injection for lateral tendinosis of the elbow. $\mathrm{Br} J$ Sports Med 1999;33:423-4.

[3] Hayes DW Jr, Gilbertson EK, Mandracchia VJ, Dolphin TF. Tendon pathology in the foot. The use of corticosteroid injection therapy. Clin Podiatr Med Surg 2000;17:723-35.

[4] van der Linden PD, van de Lei J, Nab HW, Knol A, Stricker BH. Achilles tendinitis associated with fluoroquinolones. Br J Clin Pharmacol 1999;48:433-7.

[5] van der Linden PD, van Puijenbroek EP, Feenstra J, Veld BA, Sturkenboom MC, Herings RM, et al. Tendon disorders attributed to fluoroquinolones: a study on 42 spontaneous reports in the period 1988 to 1998. Arthritis Rheum 2001;45:235-9.

[6] van der Linden PD, Sturkenboom MC, Herings RM, Leufkens HG, Stricker BH. Fluoroquinolones and risk of Achilles tendon disorders: case-control study. BMJ 2002;324:1306-7.

[7] van der Linden PD, Sturkenboom MC, Herings RM, Leufkens HM, Rowlands S, Stricker BH. Increased risk of Achilles tendon rupture with quinolone antibacterial use, especially in elderly patients taking oral corticosteroids. Arch Intern Med 2003;163:1801-7.

[8] Khaliq Y, Zhanel GG. Fluoroquinolone-associated tendinopathy: a critical review of the literature. Clin Infect Dis 2003;36:1404-10. 
[9] Stahlmann, R. Effects on connective tissue structures. In: Hooper D, Rubinstein E, editors. Quinolone antimicrobial agents. 3rd ed. Washington, DC: ASM Press; 2002. p. 441-9.

[10] Sendzik J, Lode H, Stahlmann R. Quinolone-induced arthropathy: an update focusing on new mechanistic and clinical data. Int J Antimicrob Agents 2008;33:194-200.

[11] Huston KA. Achilles tendinitis and tendon rupture due to fluoroquinolone antibiotics. N Engl J Med 1994;331:748.

[12] Zabraniecki L, Negrier I, Vergne P, Arnaud M, Bonnet C, Bertin P. et al. Fluoroquinolone induced tendinopathy: report of 6 cases. J Rheumatol 1996;23:516-20.

[13] Braun D, Petitpain N, Cosserat F, Loeuille D, Bitar S, Gillet P, et al. Rupture of multiple tendons after levofloxacin therapy. Joint Bone Spine 2004;71:586-7.

[14] Barge-Caballero E, Crespo-Leiro MG, Paniagua-Martín MJ, Muñiz J, Naya C, Bouzas-Mosquera A, et al. Quinolone-related Achilles tendinopathy in heart transplant patients: incidence and risk factors. J Heart Lung Transplant 2008;27:46-51.

[15] Tozer S, Duprez D. Tendon and ligament: development, repair and disease. Birth Defects Res C Embryo Today 2005;75:226-36.

[16] Bernard-Beaubois K, Hecquet C, Houcine O, Hayem G, Adolphe M. Culture and characterization of juvenile rabbit tenocytes. Cell Biol Toxicol 1997;13:10313.

[17] Schulze-Tanzil G, Mobasheri A, Clegg PD, Sendzik J, John T, Shakibaei M. Cultivation of human tenocytes in high-density culture. Histochem Cell Biol 2004;122:219-28.

[18] Giancotti FG, Ruoslahti E. Integrin signaling. Science 1999;285:1028-32. 
[19] van der Flier A, Sonnenberg A. Function and interactions of integrins. Cell Tissue Res 2001;305:285-98.

[20] Yang C, Li SW, Helminen HJ, Khillan JS, Bao Y, Prockop DJ. Apoptosis of chondrocytes in transgenic mice lacking collagen II. Exp Cell Res 1997;235:3703.

[21] Shakibaei M, Schulze-Tanzil G, de Souza P, John T, Rahmanzadeh M, Rahmanzadeh R, et al. Inhibition of mitogen-activated protein kinase kinase induces apoptosis of human chondrocytes. J Biol Chem 2001;276:13289-94.

[22] Shakibaei M, Pfister K, Schwabe R, Stahlmann R. Effects of ofloxacin on the ultrastructure of Achilles tendon in rats. Drugs 1999;58(Suppl 2):390-2.

[23] Shakibaei M, Stahlmann R. Ultrastructure of Achilles tendon from rats after treatment with fleroxacin. Arch Toxicol 2001;75:97-102.

[24] Shakibaei M, de Souza P, van Sickle D, Stahlmann R. Biochemical changes in Achilles tendon from juvenile dogs after treatment with ciprofloxacin or feeding a magnesium-deficient diet. Arch Toxicol 2001;75:369-74.

[25] Sendzik J, Shakibaei M, Schäfer-Korting M, Stahlmann R. Fluoroquinolones cause changes in extracellular matrix, signalling proteins, metalloproteinases and caspase-3 in cultured human tendon cells. Toxicology 2005;212:24-36.

[26] Almekinders LC, Deol G. The effects of aging, antiinflammatory drugs, and ultrasound on the in vitro response of tendon tissue. Am J Sports Med $1999 ; 27: 417-21$.

[27] Wong MW, Tang YY, Lee SK, Fu BS, Chan BP, Chan CK. Effect of dexamethasone on cultured human tenocytes and its reversibility by plateletderived growth factor. J Bone Joint Surg Am 2003;85:1914-20. 
[28] Wong MW, Tang YN, Fu SC, Lee KM, Chan KM. Triamcinolone suppresses human tenocyte cellular activity and collagen synthesis. Clin Orthop Relat Res $2004 ; 421: 277-81$.

[29] Wong MW, Tang YY, Lee SK, Fu BS. Glucocorticoids suppress proteoglycan production by human tenocytes. Acta Orthop 2005;76:927-31.

[30] Torricelli P, Fini M, Giavaresi G, Carpi A, Nicolini A, Giardino R. Effects of systemic glucocorticoid administration on tenocytes. Biomed Pharmacother 2006;60:380-5.

[31] Czock D, Keller F, Rasche FM, Häussler U. Pharmacokinetics and pharmacodynamics of systemically administered glucocorticoids. Clin Pharmacokinet 2005;44:61-98.

[32] van Zanten AR, Polderman KH, van Geijlswijk IM, van der Meer GY, Schouten MA, Girbes AR. Ciprofloxacin pharmacokinetics in critically ill patients: a prospective cohort study. J Crit Care 2008;3:422-30.

[33] Dudley MN. Pharmacokinetics of fluoroquinolones. In: Hooper, DE, Rubinstein E. editors. Quinolone antimicrobial agents. 3rd ed. Washington, DC: ASM Press; 2002. p. $115-32$.

[34] Chow AT, Fowler C, Williams RR, Morgan N, Kaminski S, Natarajan J. Safety and pharmacokinetics of multiple 750-milligram doses of intravenous levofloxacin in healthy volunteers. Antimicrob Agents Chemother 2001;45:2122-5.

[35] Oikarinen Al, Vuorio, El, Zaragoza EJ, Palotie A, Chu ML, Uitto J. Modulation of collagen metabolism by glucocorticoids. Receptor-mediated effects of dexamethasone on collagen biosynthesis in chick embryo fibroblasts and chondrocytes. Biochem Pharmacol 1988;37:1451-62.

[36] Oikarinen A, Makela J, Vuorio T, Vuorio E. Comparison on collagen gene expression in the developing chick embryo tendon and heart. Tissue and 
development time-dependent action of dexamethasone. Biochim Biophys Acta 1991;1089:40-6.

[37] Scutt N, Rolf CG, Scutt A. Glucocorticoids inhibit tenocyte proliferation and tendon progenitor cell recruitment. J Orthop Res 2006;24:173-82.

[38] Matrisian LM. Metalloproteinases and their inhibitors in matrix remodeling. Trends Genet 1990;6:121-5.

[39] Nagase H, Woessner JF Jr. Matrix metalloproteinases. J Biol Chem $1999 ; 274: 21491-4$.

[40] Riley GP, Curry V, DeGroot J, van El B, Verzijl N, Hazleman BL, et al. Matrix metalloproteinase activities and their relationship with collagen remodelling in tendon pathology. Matrix Biol 2002;21:185-95.

[41] Ritty TM, Herzog J. Tendon cells produce gelatinases in response to type I collagen attachment. J Orthop Res 2003;21:442-50.

[42] Sadowski T, Steinmeyer J. Effects of non-steroidal antiinflammatory drugs and dexamethasone on the activity and expression of matrix metalloproteinase-1, matrix metalloproteinase- 3 and tissue inhibitor of metalloproteinases- 1 by bovine articular chondrocytes. Osteoarthritis Cartilage 2001;9:407-15.

[43] Stöve J, Schöniger R, Huch K, Brenner R, Günther KP, Puhl W, et al. Effects of dexamethasone on proteoglycan content and gene expression of IL-1 $\beta$ stimulated osteoarthrotic chondrocytes in vitro. Acta Orthop Scand 2002;73:562_ 7.

[44] Boileau C, Pelletier JP, Tardif G, Fahmi H, Laufer S, Lavigne M, et al. The regulation of human MMP-13 by licofelone, an inhibitor of cyclo-oxygenases and 5-lipoxygenase, in human osteoarthritic chondrocytes is mediated by the inhibition of the p38 MAP kinase signalling pathway. Ann Rheum Dis 2005;64:891-8. 
[45] Nakazawa F, Matsuno H, Yudoh K, Watanabe Y, Katayama R, Kimura T. Corticosteroid treatment induces chondrocyte apoptosis in an experimental arthritis model and in chondrocyte cultures. Clin Exp Rheumatol 2002;20:773-81.

[46] Chrysis D, Ritzen EM, Savendahl L. Growth retardation induced by dexamethasone is associated with increased apoptosis of growth plate chondrocytes. J Endocrinol 2003;176:331-7.

[47] Van Offel JF, Schuerwegh AJ, Bridts CH, Stevens WJ, De Clerck LS. Effect of bisphosphonates on viability, proliferation, and dexamethasone-induced apoptosis of articular chondrocytes. Ann Rheum Dis 2002;61:925-8.

[48] Kempka G, Ahr HJ, Rüther W, Schlüter G. Effects of fluoroquinolones and glucocorticoids on cultivated tendon cells in vitro. Toxicol In Vitro 1996;10:743-54.

[49] Kashida Y, Kato M. Characterization of fluoroquinolone-induced Achilles tendon toxicity in rats: comparison of toxicities of 10 fluoroquinolones and effects of anti-inflammatory compounds. Antimicrob Agents Chemother 1997;41:238993.

[50] Chhajed PN, Plit ML, Hopkins PM, Malouf MA, Glanville AR. Achilles tendon disease in lung transplant recipients: association with ciprofloxacin. Eur Respir $J$ 2002;19:469-71. 
Fig. 1. Transmission electron microscopy images of tenocytes exposed to a quinolone and/or dexamethasone as well as untreated tenocytes after a 4-day culture period in monolayer culture. $(A, B)$ Untreated monolayer tenocytes (controls) showed a typical flattened shape with small cytoplasmic processes, a large mostly euchromatic nucleus with nucleoli, and well structured cytoplasm organelles such as mitochondria (arrowheads), rough endoplasmic reticulum (ER) (thin black arrows) and Golgi apparatus (white arrows). Inset (A): Synthetic activity is shown by formation of a thin matrix rim on the cell surface (star). (C-G) Exposure of tenocyte monolayer cultures to $3 \mathrm{mg} / \mathrm{L}$ ciprofloxacin (C), $3 \mathrm{mg} / \mathrm{L}$ levofloxacin (D), $0.1 \mathrm{nM}$ dexamethasone $(\mathrm{E}), 3 \mathrm{mg} / \mathrm{L}$ ciprofloxacin plus $0.1 \mathrm{nM}$ dexamethasone $(\mathrm{F})$ and 3 $\mathrm{mg} / \mathrm{L}$ levofloxacin plus $0.1 \mathrm{nM}$ dexamethasone $(G)$ led to degenerative changes such as multiple vacuoles, swelling of the rough ER (thin black arrows), clustering of swollen mitochondria (arrowheads) and degeneration of other cell organelles. The flattened monolayer tenocytes became more and more rounded, lost their microvillilike processes and became apoptotic, including areas of condensed heterochromatin in the cell nuclei and multiple and autophagic cytoplasmic vacuoles (thick black arrows). Tenocytes treated with a quinolone and dexamethasone showed more severe cellular degeneration at the ultrastructural level $(F, G)$. Magnification: $(A, C-G)$ $\times 5000$, bar $=1 \mu \mathrm{M}$; (B) $\times 10000$, bar $=2 \mu \mathrm{m}$; (inset) $\times 10000$, bar $=2 \mu \mathrm{m}$.

Fig. 2. Immunoblot of collagen type I obtained with tenocytes after a culture period of 4 days and exposure to (A) $0.1 \mathrm{nM}, 1 \mathrm{nM}, 0.1 \mu \mathrm{M}$ or $10 \mu \mathrm{M}$ dexamethasone alone (green), (B) $3 \mathrm{mg} / \mathrm{L}$ ciprofloxacin plus $0.1 \mathrm{nM}$ dexamethasone (blue) and (C) $10 \mathrm{mg} / \mathrm{L}$ ciprofloxacin plus $1 \mathrm{nM}$ dexamethasone (blue). Data are presented as densitometric units (percent of controls) from each of three replicate experiments. To allow a direct comparison, data with ciprofloxacin alone (B and $\mathrm{C}$, red), which have been published 
previously, are also included [25]. A decrease in collagen type I was observed with the highest concentration of dexamethasone and all samples after exposure to ciprofloxacin. The most pronounced decrease in this matrix protein was observed after exposure to the high concentrations of ciprofloxacin plus dexamethasone (10 $\mathrm{mg} / \mathrm{L}$ plus $1 \mathrm{nM})$.

Fig. 3. Immunoblot of $\beta_{1}$-integrin obtained with tenocytes after a culture period of 4 days and exposure to (A) $0.1 \mathrm{nM}, 1 \mathrm{nM}, 0.1 \mu \mathrm{M}$ and $10 \mu \mathrm{M}$ dexamethasone alone (green), (B) $3 \mathrm{mg} / \mathrm{L}$ ciprofloxacin plus $0.1 \mathrm{nM}$ dexamethasone (blue) and (C) $10 \mathrm{mg} / \mathrm{L}$ ciprofloxacin plus $1 \mathrm{nM}$ dexamethasone (blue). Data are presented as densitometric units (percent of controls) from each of three replicate experiments. To allow a direct comparison, data with ciprofloxacin alone ( $B$ and $C$, red), which have been published previously, are also included [25]. A decrease in $\beta_{1}$-integrin was observed with the two highest concentrations of dexamethasone and all samples after exposure to ciprofloxacin. The decrease was more pronounced after combined exposure in comparison with exposure to dexamethasone or ciprofloxacin alone.

Fig. 4. Immunoblot of vinculin obtained with tenocytes after a culture period of 4 days and exposure to (A) $0.1 \mathrm{nM}, 1 \mathrm{nM}, 0.1 \mu \mathrm{M}$ and $10 \mu \mathrm{M}$ dexamethasone (green), (B) 3 $\mathrm{mg} / \mathrm{L}$ ciprofloxacin plus $0.1 \mathrm{nM}$ dexamethasone (blue) and (C) $10 \mathrm{mg} / \mathrm{L}$ ciprofloxacin plus $1 \mathrm{nM}$ dexamethasone (blue). Data are presented as densitometric units (percent of controls) from each of three replicate experiments. To allow a direct comparison, data with ciprofloxacin alone (B and C, red), which have been published previously, are also included [25]. A decrease in vinculin was observed with the two highest concentrations of dexamethasone and all samples after exposure to ciprofloxacin. Overall, a similar pattern of changes was observed as obtained with collagen type I. 
Fig. 5. Immunoblot of matrix metalloproteinase-1 (MMP-1) obtained with tenocytes after a culture period of 4 days and exposure to (A) $0.1 \mathrm{nM}, 1 \mathrm{nM}, 0.1 \mu \mathrm{M}$ and $10 \mu \mathrm{M}$ dexamethasone alone (green), (B) $3 \mathrm{mg} / \mathrm{L}$ ciprofloxacin plus $0.1 \mathrm{nM}$ dexamethasone (blue) and (C) $10 \mathrm{mg} / \mathrm{L}$ ciprofloxacin plus $1 \mathrm{nM}$ dexamethasone (blue). Data are presented as densitometric units from each of three replicate experiments; the range of all controls (0.01-0.12 densitometric units) is presented as a shaded area. To allow a direct comparison, data with ciprofloxacin alone ( $B$ and $C$, red), which have been published previously, are also included [25]. A clear-cut increase in MMP-1 was observed with the two highest concentrations of dexamethasone; moreover, after exposure to $10 \mathrm{mg} / \mathrm{L}$ ciprofloxacin plus $1 \mathrm{nM}$ dexamethasone all three values are above the control range.

Fig. 6. Immunoblot of matrix metalloproteinase-13 (MMP-13) obtained with tenocytes after a culture period of 4 days and exposure to (A) $0.1 \mathrm{nM}, 1 \mathrm{nM}, 0.1 \mu \mathrm{M}$ and $10 \mu \mathrm{M}$ dexamethasone alone (green), (B) $3 \mathrm{mg} / \mathrm{L}$ ciprofloxacin plus $0.1 \mathrm{nM}$ dexamethasone (blue) and (C) $10 \mathrm{mg} / \mathrm{L}$ ciprofloxacin plus $1 \mathrm{nM}$ dexamethasone (blue). Data are presented as densitometric units from each of three replicate experiments; the range of all controls (0.0-0.12 densitometric units) is presented as a shaded area. To allow a direct comparison, data with ciprofloxacin alone (B and $C$, red), which have been published previously, are also included [25]. A significant increase in MMP-13 was only observed with the highest concentration of dexamethasone. This protein was strongly increased after exposure to $10 \mathrm{mg} / \mathrm{L}$ ciprofloxacin plus $1 \mathrm{nM}$ dexamethasone. 
Fig. 7. Western blot of matrix metalloproteinase-13 (MMP-13) of human tenocytes after 1,2, 3 or 4 days in culture. Cells were exposed to ciprofloxacin or levofloxacin at a concentration of $10 \mathrm{mg} / \mathrm{L}$ in combination with $1 \mathrm{nM}$ dexamethasone. A clear-cut time dependency of the effect was noticed. Changes were more pronounced with ciprofloxacin than with levofloxacin.

Fig. 8. Time dependency of the effects of dexamethasone alone and in combination with ciprofloxacin or levofloxacin on (A) matrix metalloproteinase-13 (MMP-13) and (B) caspase-3. Columns represent results of Western blot analysis (mean values of densitometric units; $n=3$ ). Ranges of control values were 10.0-63.3 densitometric units (MMP-13) and 6.7-20.0 densitometric units (caspase-3). Tenocytes were analysed after a culture period of 1,2, 3 or 4 days. For MMP-13, the combination of the quinolones with dexamethasone at the higher concentrations $(10 \mathrm{mg} / \mathrm{L}$ plus 1.0 $\mathrm{nM}$, respectively) induced a clear-cut time-dependent effect that was not observed with dexamethasone alone. Similar effects were observed for caspase-3 at both concentration levels ( $3 \mathrm{mg} / \mathrm{L}$ plus $0.1 \mathrm{nM}$ and $10 \mathrm{mg} / \mathrm{L}$ plus $1.0 \mathrm{nM}$ ).

Fig. 9. Immunoblot of caspase-3 obtained with tenocytes after a culture period of 4 days and exposure to (A) $0.1 \mathrm{nM}, 1 \mathrm{nM}, 0.1 \mu \mathrm{M}$ and $10 \mu \mathrm{M}$ dexamethasone alone (green), (B) $3 \mathrm{mg} / \mathrm{L}$ ciprofloxacin plus $0.1 \mathrm{nM}$ dexamethasone (blue) and (C) $10 \mathrm{mg} / \mathrm{L}$ ciprofloxacin plus $1 \mathrm{nM}$ dexamethasone (blue). Data are presented as densitometric units from each of three replicate experiments; the range of all controls $(0.0-0.04$ densitometric units) is presented as a shaded area. To allow a direct comparison, data with ciprofloxacin alone (B and $C$, red), which have been published previously, are also included [25]. An increase in caspase-3 was observed with the two highest concentrations of dexamethasone as well as after exposure to ciprofloxacin plus 
dexamethasone at both concentration levels. However, for $10 \mathrm{mg} / \mathrm{L}$ ciprofloxacin plus $1.0 \mathrm{nM}$ dexamethasone, changes were less pronounced than for $3 \mathrm{mg} / \mathrm{L}$ ciprofloxacin plus $0.1 \mathrm{nM}$ dexamethasone. 


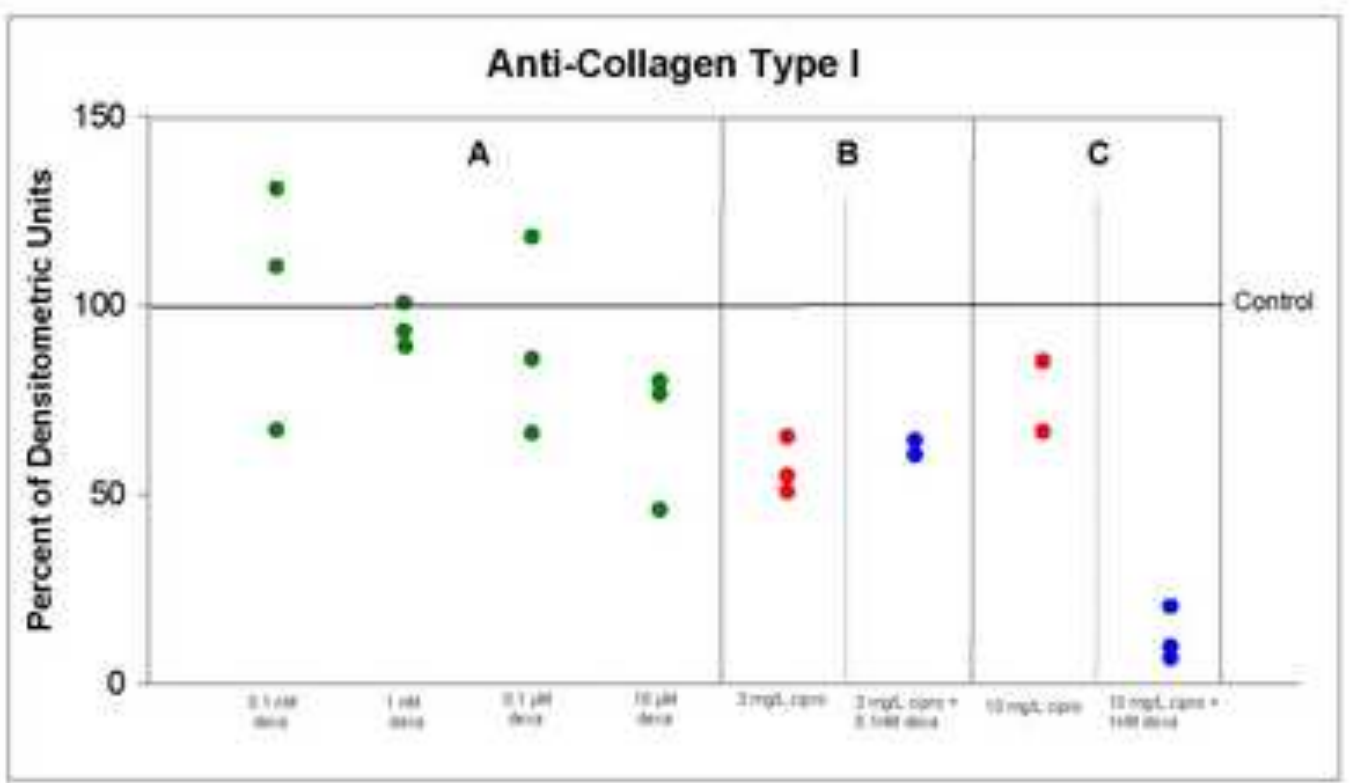

rage 30 of 37 


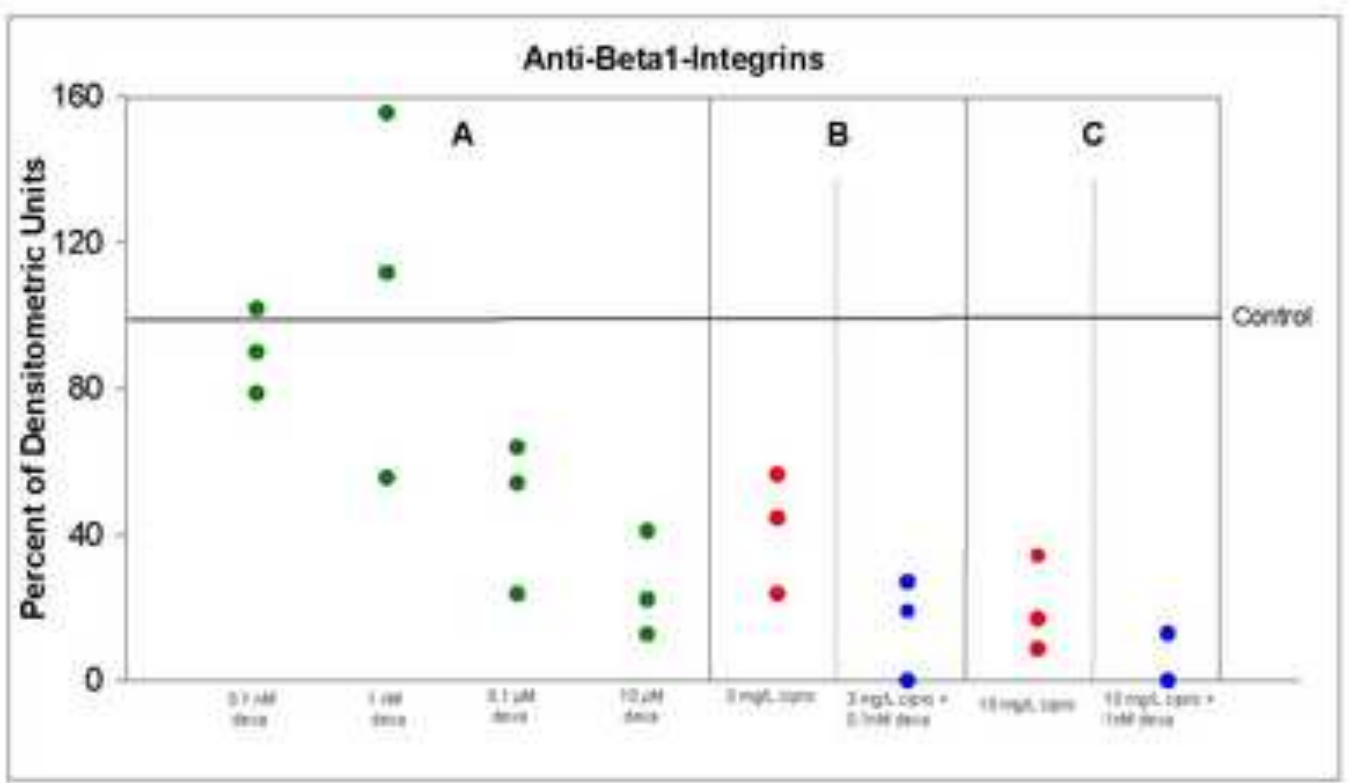

rage 31 of 37 


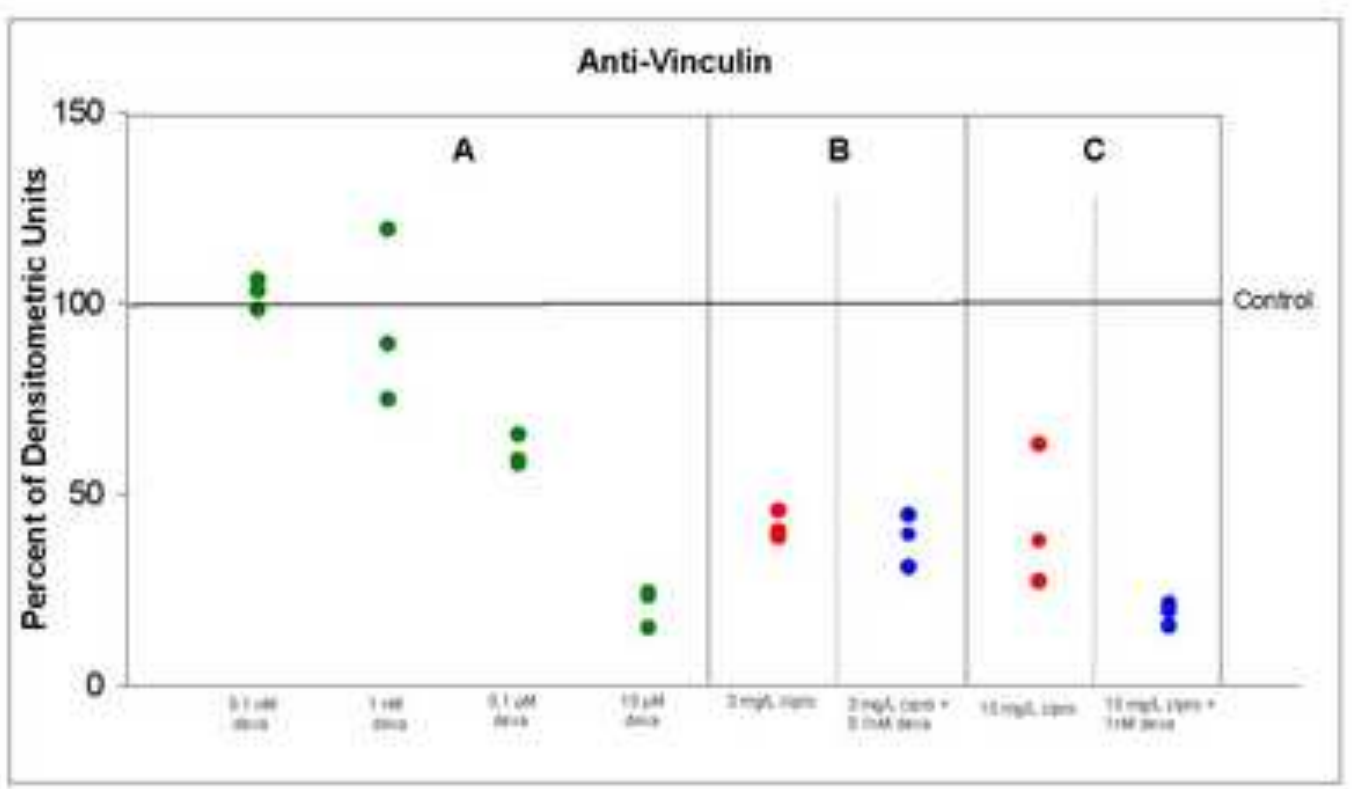

rage 32 of 37 


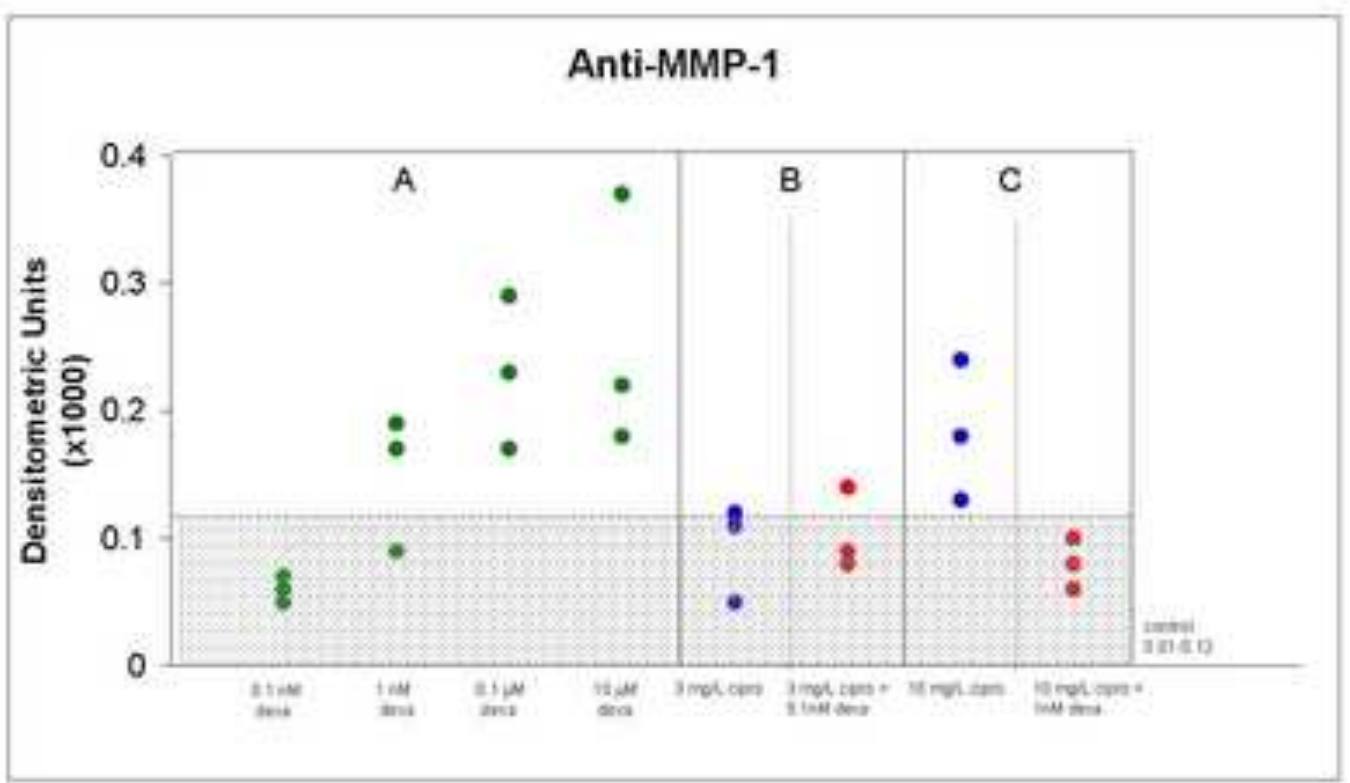




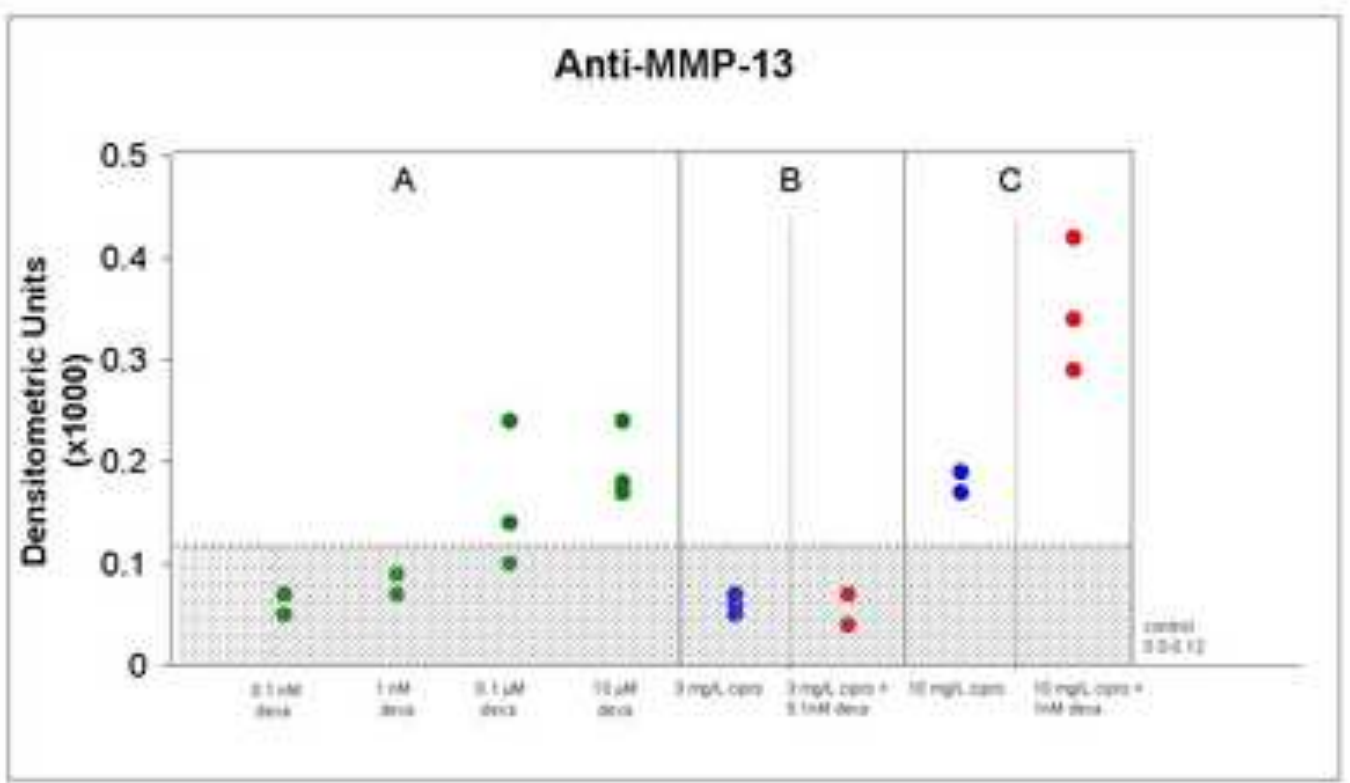

rage 34 of 37 


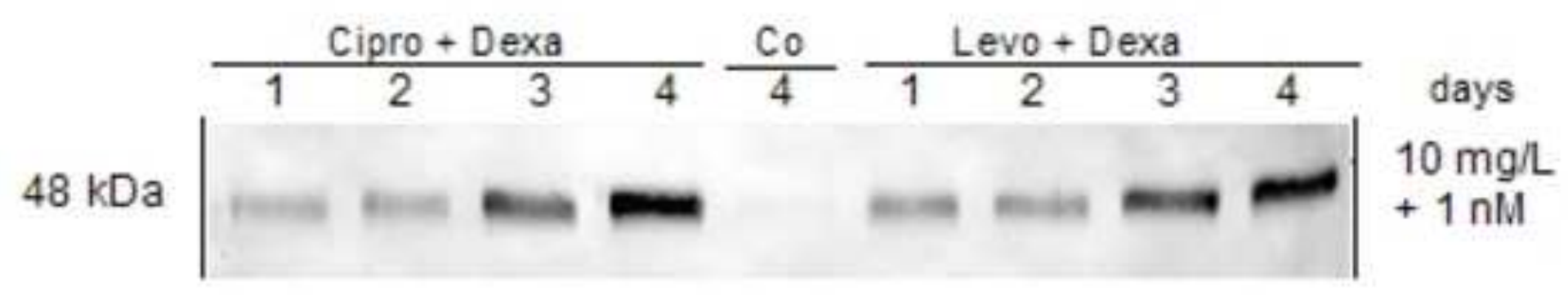

\section{Blot: anti-MMP-13}


A

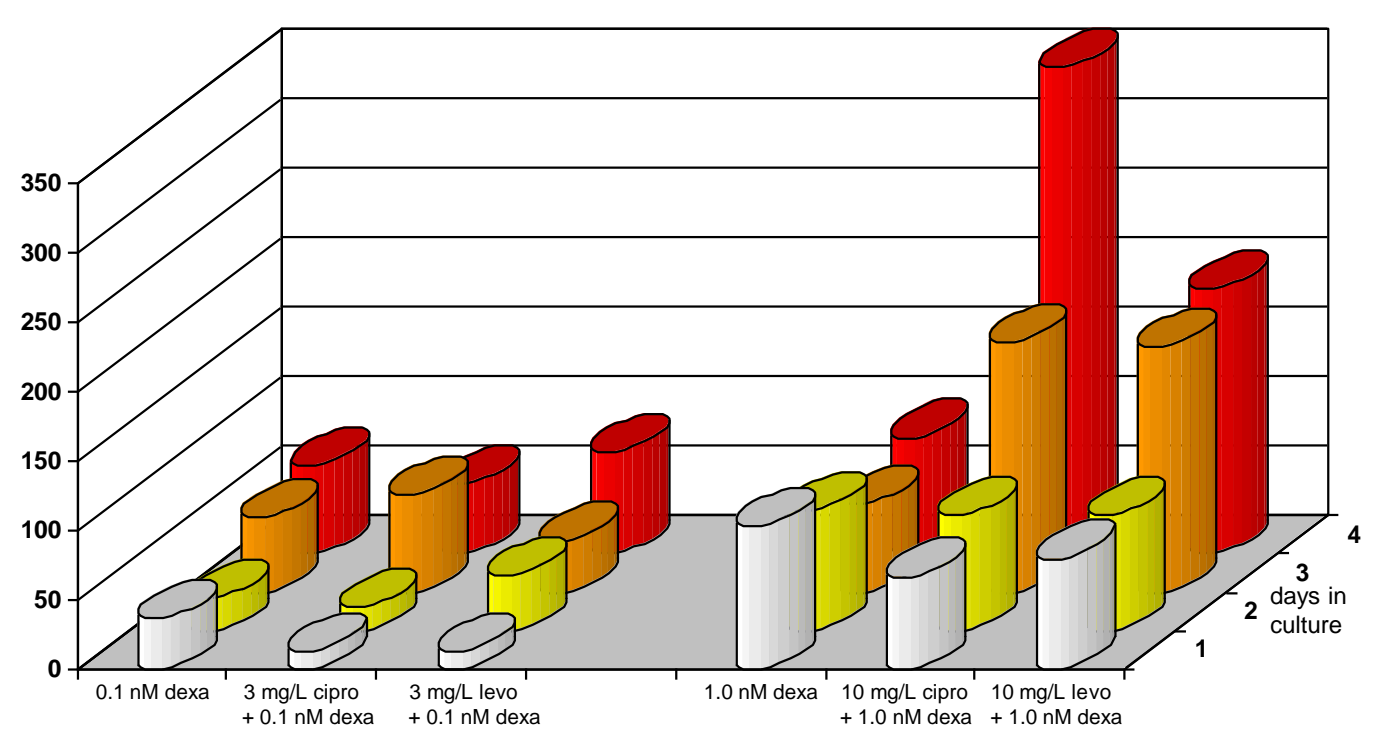

B

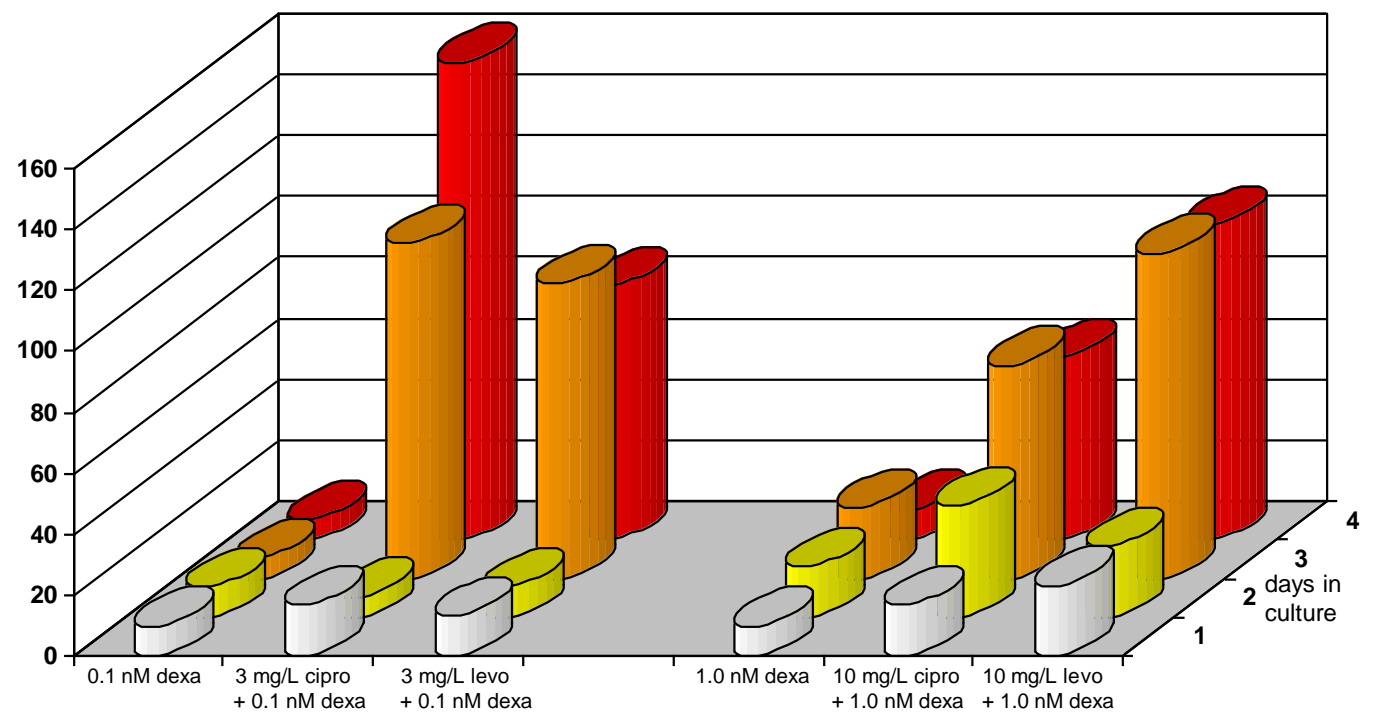




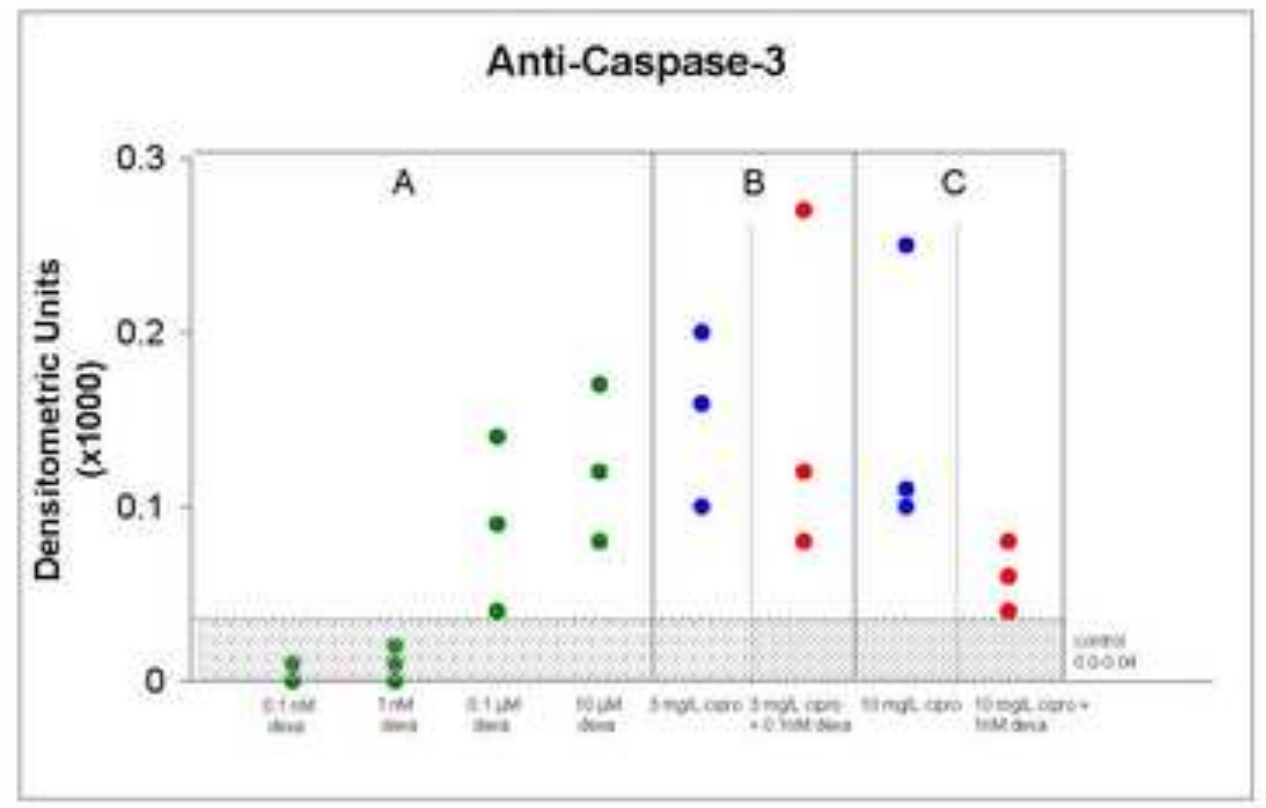

rage 37 of 37 